\title{
Pemanggilan Murid Secara Sengaja Berdasarkan Teladan Tuhan Yesus
}

\author{
Sari Saptorini \\ Sekolah Tinggi Teologi Baptis Indonesia Semarang \\ sarisaptorini@gmail.com
}

\begin{abstract}
ABSTRAK
The Lord Jesus set an example as well as a command in the ministry of making disciples. He began His ministry in this world by calling out the disciples who would be with Him and He taught specifically so that finally they could carry out the command to make disciples of all nations. Through a study of the Gospels of Matthew, Mark and Luke regarding the calling of disciples, it was found that the Lord Jesus called people intentionally and offered invitations to become His disciples. Calling to be a disciple of Jesus means a call to repentance and forgiveness of sins and to follow Him according to His purpose. He did not call people aimlessly. Therefore, in calling His disciples, the Lord Jesus also gave a vision of calling. He communicated the vision clearly so that it could be fully understood by His disciples. That vision was in line with the Great Commission given by His disciples to His ascension to heaven. As such, calling the disciples intentionally is intended to be carried out continuously by anyone who welcomes the call to be a disciple of Christ.
\end{abstract}

Kata kunci: pemuridan, pemanggilan murid, sengaja, murid khusus, visi panggilan

\section{PENDAHULUAN}

Pelayanan Tuhan Yesus di bumi tidak dapat dipisahkan dari pemuridan. Kristus memandang pemuridan sebagai sebuah mandat, bukan pilihan. Pelayanan-Nya memodelkan pemuridan, dan perkataan terakhir-Nya memerintahkan pemuridan. ${ }^{1}$ Hal itu nampak di dalam Alkitab bahwa interaksi Yesus dengan murid-murid-Nya terus berlangsung sejak pemanggilan para murid yang pertama hingga kebangkitanNya dari antara orang mati. Yesus bukan hanya memanggil 12 orang yang dikhususkan- Nya, melainkan juga mempersiapkan mereka untuk menjadikan segala bangsa murid-Nya. Pada waktu Tuhan Yesus akan naik ke surga, Ia memberikan sebuah perintah kepada muridmurid-Nya. Perintah tersebut dikenal sebagai Amanat Agung yang dicatat dalam Matius 28:19- 20, "Karena itu pergilah, jadikanlah semua bangsa murid-Ku dan baptislah mereka dalam nama Bapa dan Anak dan Roh Kudus, dan ajarlah mereka melakukan segala sesuatu yang telah Kuperintahkan kepadamu. Dan ketahuilah, Aku menyertai kamu senantiasa sampai kepada akhir zaman." Kebanyakan gereja memahami Matius 28:19-20 sebagai ayat-ayat yang menekankan penginjilan dunia. Akan tetapi, penekanan utama ayat tersebut adalah pemuridan, di mana menjadikan murid merupakan sasaran dari Amanat Agung.

Peter Wagner dalam Strategi Perkembangan Gereja, menyatakan bahwa di dalam Amanat Agung, ada empat kata kerja: "pergilah," "jadikanlah murid-Ku," "baptislah," dan "ajarlah". Dalam bahasa aslinya, yaitu dalam bahasa Yunani, tiga dari keempat kata kerja di atas, yakni "pergilah", "baptislah" dan "ajarlah" adalah kata kerja bantu dan hanya satu kata kerja yang berupa perintah, yaitu “jadikanlah murid-Ku”. Amanat Agung hanya akan terpenuhi jika setiap orang percaya menjadi murid Yesus. $^{2}$ Seorang murid berarti seorang
${ }^{1}$ Eric Russ, Discipleship Defined (Maitland, Florida: XulonPress, 2010), 20.
2 C. Peter Wagner, Strategi Perkembangan Gereja (Malang: Yayasan Penerbit Gandum Mas, 1996), 37. 
"pembelajar". Dengan demikian, pemuridan bukan menjadikan orang-orang untuk menjadi murid bagi sang pembina murid, melainkan menghasilkan murid untuk belajar kepada Yesus. ${ }^{3}$

Pemuridan adalah proses di mana seseorang menjadi semakin serupa dengan Kristus. Proses tersebut meliputi baik masuknya ke dalam proses (keselamatan) dan bertumbuh di dalam proses (pengudusan). Pemuridan sejati memiliki dua komponen. Pertama adalah pengajaran tentang Kristus: siapa Dia, apa yang dilakukan-Nya, apa yang diajarkan-Nya sebagaimana dicatat dalam Alkitab, serta mengajarkan tentang orang- orang yang menjadi contoh unggulan dalam kehidupan mereka untuk menjadi serupa dengan Kristus. Komponen kedua adalah meniru orang-orang yang memanifestasikan sifat Kristus dalam hidup mereka dan menghidupi kebenaran Kristen. ${ }^{4}$

Pelayanan pembuat murid merupakan kewajiban bagi gereja, terlebih bagi seorang gembala sidang. Greg Ogden menyatakan, "We have undiscipled church because its leaders have not made discipling their primary focus." ${ }^{5}$ Hal itu berarti bahwa gembala sidang seharusnya menjadikan pemuridan sebagai fokus utama mereka sehingga jemaat akan bertumbuh menjadi murid-murid Kristus yang melayani. Bahkan Bill Hull juga menyatakan bahwa membuat murid adalah satu-satunya pekerjaan penting dari seorang gembala sidang dimana panggilan untuk menjadikan murid jelas merupakan pekerjaan bagi gembala sidang seperti menari bagi balerina dan berenang bagi lumba-lumba. ${ }^{6}$

\section{METODE PENELITIAN}

Penelitian ini dilakukan dengan menggunakan metode analisa teologi biblika dengan melakukan eksegesis untuk menafsirkan atau mengartikan teks-teks

\footnotetext{
3 Bill Hull, Choose the Life (Surabaya: Literatur Perkantas Jawa Timur, 2012), 34-5.

${ }^{4}$ Dallas Theological Seminary: Bibliotheca Sacra Volume 160. Dallas Theological Seminary, 2003; 2004, S. vnp.160.638.221-160.638.234.

${ }^{5}$ Greg Ogden, Transforming Discipleship (Illinois: Intervarsity Press, 2009), 40.
}

yang ada. Selain itu, penelitian ini juga menggunakan metode riset kepustakaan dimana peneliti menggunakan informasi atau data empiric yang telah dikumpulkan oleh orang lain baik dalam bentuk laporan hasil penelitian maupun laporan-laporan resmi yang dapat digunakan untuk riset kepustakaan.

\section{PEMBAHASAN}

Tuhan Yesus adalah teladan sempurna mengenai bagaimana pemuridan dilaksanakan. Tuhan Yesus bukan hanya memberikan perintah yang harus ditaati oleh gereja-Nya terlebih oleh hamba- hamba-Nya yang dipercaya untuk menggembalakan umat-Nya supaya memuridkan mereka, melainkan juga memberikan suatu model pemuridan yang disengaja. Model pemuridan Sengaja Yesus seharusnya menjadi model yang ditiru oleh orang-orang yang menyatakan diri sebagai murid- murid-Nya, sebagaimana Richard Peace dalam Eldin Villafane berkata, "As the Master, so the disciples. The pattern which the Son of Man will live out is the pattern that his disciples must follow."

Pelayanan pemuridan Yesus diawali dengan pemanggilan secara Sengaja orangorang yang akan menjadi murid-murid-Nya. Pemanggilan murid-murid-Nya yang pertama melibatkan empat orang nelayan di danau Galilea. Ketiga Injil yang menuliskan peristiwa tersebut dalam Matius 4:18-22, Markus 1:16-20, Lukas 5:1-11 memberikan catatan yang sama mengenai empat murid pertama Yesus. Mereka adalah Simon Petrus, Andreas, Yakobus, dan Yohanes.

Dari pemanggilan empat murid pertama itu, Matius menekankan pada panggilan Yesus yang menuntut murid-murid untuk meninggalkan segala sesuatu untuk mengikuti Dia. Hal itu ditunjukkan dengan laporan Matius bahwa Petrus dan Andreas segera "meninggalkan jala mereka", sedangkan Yakobus dan Yohanes "meninggalkan perahu

${ }^{6}$ Bill Hull, The Disciple-Making Pastor: Leading Others on the Journey of Faith (Grand Rapids, Michigan: Baker Books, 2007), 93.

${ }^{7}$ Eldin Villafane, Beyond Cheap Grace: A Call to Radical Disciplehip, Incarnation, and Justice (Grand Rapids: Eerdmands, 2006), 15. 
serta ayahnya" lalu mengikuti Yesus. $^{8}$ Dengan demikian, setelah meninggalkan rumah dan pekerjaan mereka, murid-murid pertama tersebut tinggal bersama Yesus serta menemani-Nya ke mana pun Ia pergi. Mereka mendengarkan pengajaran-Nya serta mengamat-amati tindakan-Nya.

Di dalam Matius, Markus dan Lukas, ada perkataan penting Yesus kepada empat orang yang bersedia untuk mengikut Dia, yakni: "Mari, ikutlah Aku, dan kamu akan Kujadikan penjala manusia." deu/te ovpi,sw mou(kai. poih,sw u'ma/j a'l iei/j avnqrw,pwn (Matius 4:19; Markus 1:17; bandingkan Lukas 5:10). Secara harfiah, kalimat tersebut memiliki arti: "Lalu Ia berkata kepada mereka, \{Ikutlah $\}$ Aku, dan Aku akan membuat kamu nelayan- nelayan (menjala) manusia-manusia. Frase "Ikutlah Aku" yang diucapkan Yesus, dalam bahasa Yunani adalah deu/te ovpi,sw mou, berarti datang dan mengikuti di belakang Yesus. Dalam panggilannya kepada Matius (Lewi), Yesus juga berkata, "Ikutlah Aku" (avkol ou,qei moiA ) dalam bentuk verb imperative present active $2^{\text {nd }}$ person singular. Kata avkol ouqe, $w$ mengandung arti mengikuti seseorang sebagai muridnya, menyertai dan menaati. Selain peristiwa pemanggilan empat murid pertama, ketiga Injil Sinoptik juga mencatat pemanggilan salah satu murid yang lain, yaitu Matius atau Lewi sebagaimana tertulis dalam teks Alkitab: Matius 9:9-13; Markus 2:13-17; Lukas 5:27-32. Matius adalah seorang pemungut pajak; ia dijauhi oleh orangorang karena kerjasamanya dengan penguasa Roma. Tetapi terhadap panggilan Yesus, ia menaati dan mengikuti-Nya. Pada masa Yudaisme abad pertama, posisi sosial bagi "orang-orang berdosa" dan "pemungut cukai" begitu rendah. "Orang-orang berdosa" merujuk kepada orang-orang yang gagal mempertahankan standar kaum Farisi yang tinggi mengenai pelaksanaan ritual keagamaan. Sedangkan "pemungut cukai" adalah orang- orang yang dipandang hina dan diasingkan oleh semua orang. Seorang

\footnotetext{
${ }^{8}$ James Montgomery Boice, The Gospel of Matthew Volume 1 (Grand Rapids, Michigan: Baker Books, 2001), 64.

${ }^{9}$ Boice, The Gospel of Matthew, 65.
}

pemungut cukai bukan hanya tidak diperbolehkan menjabat sebagai pegawai negeri atau bahkan bersaksi di pengadilan untuk kasus perdata maupun pidana. Selain itu, uang dari dompet pemungut cukai dianggap cemar sehingga tidak dapat diterima di Bait Suci, juga tidak dapat didermakan kepada orang miskin, bahkan tidak dapat ditukarkan pula. Ketika orang-orang Farisi protes akan kebersamaan Yesus dengan "orang-orang berdosa" tersebut, Ia menjawab, "Bukan orang sehat yang memerlukan tabib, tetapi orang sakit. Jadi pergilah dan pelajarilah arti firman ini: Yang Kukehendaki ialah belas kasihan dan bukan persembahan, karena Aku datang bukan untuk memanggil orang benar, melainkan orang berdosa" (Matius 9:12-13). Penjelasan-Nya menunjukkan bahwa perintah untuk mengikuti Yesus bukan hanya mengikuti secara jasmaniah, atau sekedar undangan untuk belajar tentang Dia lebih banyak lagi untuk seseorang dapat menjadi murid-Nya, melainkan berbalik dari dosa kepada keselamatan, untuk disembuhkan oleh Allah. ${ }^{9}$

Panggilan Yesus terhadap Matius secara langsung memintanya untuk menjadi muridNya. Kata ini berbeda dengan ajakan Yesus kepada keempat murid pertama, sebagaimana telah dijelaskan di atas, namun maksud Yesus supaya empat orang yang dipanggil-Nya tersebut menjadi murid-Nya dapat dipahami dengan jelas oleh mereka, dibuktikan dengan Petrus dan Andreas yang meninggalkan jala mereka, serta Yakobus dan Yohanes yang meninggalkan perahu dan ayahnya, lalu mengikuti (avkol ouqe, $w$ ) Yesus. ${ }^{10}$ Dengan demikian, panggilan untuk pertobatan itu bukan saja ditujukan Yesus kepada Matius yang adalah seorang pemungut cukai, melainkan juga terhadap empat murid pertama. Di dalam Matius maupun Lukas, panggilan kepada murid-murid pertama didahului oleh catatan khotbah pertama Kristus, yang berfokus pada kata "Bertobatlah" (Matius 4:7). Di dalam Lukas, catatan serupa ada pada kisah keajaiban intervensi Yesus ketika para murid menjala ikan.

Hasilnya, mereka memperoleh begitu banyak ikan hingga jala mereka mulai koyak. Kisah tersebut berakhir dengan kekaguman

10 Perjanjian Baru Interlinear Yunani-Indonesia dan Konkordansi Perjanjian Baru (PBIK), diterjemahkan oleh Hasan Sutanto (Jakarta: Lembaga Alkitab Indonesia, 2006), 36 
Petrus akan kekudusan Kristus, yang membuat ia berseru, "Pergilah dari padaku, Tuhan; sebab aku ini orang berdosa" (Lukas 5:8). ${ }^{11}$ Respon Yesus terhadap Petrus adalah "Jangan takut". Kata "jangan takut" itu adalah mh. f obou/ $\backslash$ dalam bentuk verb imperative middle $2^{\text {nd }}$ person singular ${ }^{12}$ yang berarti bahwa Yesus memerintahkan kepada mereka untuk tidak takut datang kepada-Nya oleh keberadaannya yang berdosa karena ada pengampunan yang disediakan-Nya bagi orang yang mau bertobat.

Yesus memanggil orang untuk menjadi murid-Nya bertobat meninggalkan dosa-dosanya dan berbalik kepada Allah yang hidup untuk memperoleh pengampunan dosa. Pertobatan merupakan langkah awal untuk seseorang bertumbuh dalam iman sebagai murid Yesus, sebagaimana dikatakan oleh James Moore bahwa panggilan pada pemuridan merupakan panggilan untuk bertumbuh dalam iman. ${ }^{13}$ Jadi, pemanggilan murid merupakan sebuah undangan kepada seseorang untuk bertobat, meninggalkan dosa-dosanya dan mengikut Yesus.

Dietrich Bonhoeffer mengatakan bahwa respon para murid terhadap undangan Yesus adalah tindakan ketaatan, bukan sebuah pengakuan iman dalam Yesus. ${ }^{14}$ Hal itu berarti bahwa kesediaan seseorang untuk menjadi murid Yesus merupakan perwujudan dari iman kepada Yesus, sebagaimana dikatakan oleh Bonhoeffer: "Only he who believes is obedient, and only he who is obedient believes." 15 Bill Hull, dalam The Complete Book of Discipleship, mengatakan bahwa frase "ikutlah Aku" merupakan suatu undangan dan bukan permintaan.

Undangan tersebut dapat diterima atau ditolak oleh orang yang diundangNya. Lukas 9:57-62 berbicara mengenai hal mengikut Yesus. Berdasarkan respon Yesus

\footnotetext{
11 Ibid., 66.

12 PBIK, 325.

13 James W. Moore, Jesus Parable about Discipleship (Nashville, Tenessee: Abingdon Press, 2009)

14 Dietrich Bonhoeffer, The Cost of Discipleship (London: SCM Press, 2001), 15.
}

terhadap orang pertama, nampaknya ia meminta jaminan bahwa Yesus akan menyediakan tempat tinggal dan makanan. Orang kedua menolak undangan Yesus dengan berkata bahwa ia ingin menguburkan ayahnya, yang dengan kata lain berkata bahwa ia tidak dapat mengikut Yesus pada saat itu, dan mungkin suatu hari nanti ketika ia merasa waktunya tepat. Orang ketiga nampaknya ingin mengikut-Nya, tetapi ia minta izin untuk berpamitan kepada keluarganya terlebih dahulu. Yesus melihat hal ini sebagai alasan yang baik, namun alasan untuk tidak berkata ya. Sekalipun demikian, Yesus tidak membenci orang-orang yang menolak-Nya. Dan Ia menginvestasikan diri sepenuhnya di dalam orang-orang yang bersedia mengikuti-Nya. ${ }^{16}$

Sebagaimana Yesus membayar mahal demi orang- orang yang mengikuti-Nya, demikian mahal pula harga dari mengikut Yesus itu sendiri. Boice mencatat bahwa ada kebenaran-kebenaran penting yang harus diajarkan dalam frase "Ikutlah Aku", yakni sebagai murid Kristus seseorang harus hidup dalam ketaatan, pertobatan, ketundukan, dan komitmen. ${ }^{17}$ Seseorang yang mengikut Yesus berarti menyerahkan seluruh kehidupannya tanpa memiliki keinginan untuk mengendalikan hidupnya sendiri selain ketaatan dan ketundukkan kepada Yesus sebagaimana dikatakan oleh Bonhoeffer, "To follow in his step is something which is void of all content. It gives us no intelligible programme for a way of life, no goal or ideal to strive after."18

Undangan Yesus untuk mengikuti-Nya itu bersifat personal yang mengandung makna tinggal bersama dengan melibatkan suatu hubungan, persekutuan yang erat dan persahabatan. Kekuatan persahabatan merupakan motivasi utama untuk berpartisipasi dalam pelayanan. Jadi, mengikut Yesus bersifat pribadi, itulah mengapa Allah merancang pemuridan sebagai seseorang yang menolong

\footnotetext{
15 Ibid., 16.

16 Bill Hull, The Complete Book of Discipleship (Colorado Springs: NavPress, 2006), 175-6.

17 James Montgomery Boice, Christ's Call to Discipleship (Grandrapids, Michigan: Kregel Publications, 1998), 1719.

${ }^{18}$ Bonhoeffer, 16.
} 
orang lain untuk bersama-sama mengikut Yesus. ${ }^{19}$

Senada dengan Boice, Eddie Gibbs mengatakan bahwa pemuridan menuntut tanggapan pribadi terhadap panggilan Yesus untuk mengikuti-Nya. Pemuridan tidak terbatas untuk memilih sekelompok orang kudus, pemuridan adalah panggilan kepada setiap orang percaya yang dilakukan secara sengaja. Bukan sekedar bertemu Yesus pada akhir perjalanan seseorang, melainkan tanggapannya terhadap undangan Yesus untuk bersama-sama dengan-Nya melalui keseluruhan perjalanan hidupnya. $^{20}$ Dengan demikian, pemanggilan murid melibatkan baik itu undangan dari Yesus maupun tanggapan dari orang yang menerima undangan tersebut.

Dalam pemanggilan para murid tersebut, Injil Lukas memberikan catatan menarik pada pasal 6:12-16, yakni Yesus memilih dari antara murid-murid-Nya 12 orang secara khusus dan sengaja yang disebut-Nya rasul. Dengan demikian, nampak bahwa ada lebih dari 12 orang yang telah bersedia menerima undangan Yesus untuk dipanggil menjadi murid-murid-Nya. Sebelum memilih 12 murid tersebut, Yesus semalam-malaman berdoa kepada Allah. Lukas 6:12, "Pada waktu itu pergilah Yesus ke bukit untuk berdoa dan semalammalaman Ia berdoa kepada Allah." Dalam bahasa aslinya dikatakan, VEge,neto de. evn $t$ ailj h`me,raij tau,taij evxel qei/n auvto.n eivj to. o;roj proseu,xasqai( kai. $h=n$ di anuktereu,wn evn th/ proseuch/ tou/ qeou/A ${ }^{21}$ yang secara harfiah berarti "Adapun pada waktu itu Dia pergi ke luar ke gunung untuk berdoa, lalu \{melewati semalam suntuk\} dalam doa (kepada) Allah." Kedua belas murid itu dipanggil secara khusus. Mereka memang dipanggil melalui undangan yang disampaikan oleh Yesus kepada mereka, namun pemilihan untuk menjadi satu kelompok atau komunitas tersendiri yang disebut-Nya sebagai rasul (apostolos: utusan) merupakan suatu pemilihan yang dilakukan

${ }^{19}$ Hull, 176-7.

20 Eddie Gibbs, Kepemimpinan Gereja Masa Mendatang (Jakarta: BPK Gunung Mulia, 2010), 85. oleh Yesus. Pada tulisan ketiga Injil disebutkan nama-nama kedua belas orang pilihan tersebut, yaitu: Simon yang disebut Petrus dan Andreas saudaranya, dan Yakobus anak Zebedeus dan Yohanes saudaranya, Filipus dan Bartolomeus, Tomas dan Matius pemungut cukai, Yakobus anak Alfeus, dan Tadeus, Simon orang Zelot dan Yudas Iskariot yang mengkhianati Dia.

Rupanya perkara memilih 12 murid khusus tersebut bukanlah perkara mudah bagi Yesus. Pemilihan orang-orang yang akan menjadi sahabat-sahabat terdekat- Nya itu merupakan peristiwa penting, sebab mencakup panggilan Petrus yang akan menjadi pemimpin (nama Simon Petrus selalu menduduki urutan pertama dalam daftar 12 murid), serta panggilan Yudas Iskariot yang akan mengkhianati-Nya. ${ }^{22}$

Melihat Lukas dua kali menyebutkan bahwa Yesus berdoa sepanjang malam sebelum mengambil keputusan terakhir, maka dapat disimpulkan bahwa doa merupakan tindakan yang tidak dapat diabaikan, bahkan langkah awal sebelum memilih seorang murid. Dapat dikatakan bahwa bukan Yesus yang memilih para murid-Nya, melainkan Bapa. Hal itu dinyatakan di dalam Injil Yohanes 17:6-7 mengenai doa Yesus bagi murid-murid-Nya pada malam sebelum penyaliban-Nya, "Aku telah menyatakan nama-Mu kepada semua orang, yang Engkau berikan kepada-Ku dari dunia. Mereka itu milik-Mu dan Engkau telah memberikan mereka kepada-Ku dan mereka telah menuruti firman-Mu. Sekarang mereka tahu, bahwa semua yang Engkau berikan kepada-Ku itu berasal dari pada-Mu."

Dengan mengetahui bahwa langkah pertama Yesus adalah berdoa, maka dapat dilihat akan keberpusatan Yesus pada kehendak Bapa. Pemanggilan murid tersebut bukan merupakan kehendak Yesus sendiri, melainkan kehendak Bapa sebagaimana Yesus menyatakan bahwa Ia datang untuk melakukan kehendak Bapa yang mengutus-Nya (Yohanes 6:38-39).

Dengan demikian, dapat diketahui bahwa Yesus menempatkan doa sebagai hal yang terutama di dalam persiapan bagi-Nya untuk memanggil murid-murid-Nya untuk masuk ke dalam suatu komunitas khusus yang sengaja diciptakan-Nya.

\footnotetext{
${ }^{21}$ PBIK, 332.

${ }^{22}$ Tafsir Perjanjian Baru 3: Injil Lukas (Yogyakarta: Kanisius, 1989), 100-1.
} 
Setelah Ia berdoa, pada waktu yang ditentukan- Nya, Ia mengadakan pemilihan akan siapa saja yang akan menjadi murid khusus atau yang disebut-Nya sebagai rasul. Lukas mencatat, "Ketika hari siang, Ia memanggil murid-murid-Nya kepada-Nya, lalu memilih dari antara mereka dua belas orang yang disebut-Nya, rasul." Dari kalimat tersebut dapat diketahui bahwa pada saat itu Yesus memiliki lebih dari dua belas orang murid, namun Ia mengadakan pemilihan orang-orang khusus yang akan diperlengkapi dengan kuasa atas setan dan melenyapkan penyakit serta diutus-Nya untuk memberitakan Injil (Matius 10:1; Markus 3:13-14).

Pemilihan dua belas orang murid itu bukan berarti bahwa Yesus mengabaikan yang lainnya. Bahkan nampaknya di dalam kelompok murid-murid khusus tersebut, Petrus, Yakobus dan Yohanes menikmati hubungan yang lebih istimewa dibandingkan dengan kesembilan murid lainnya. Mereka mendapat hak istimewa untuk masuk ke dalam kamar Yairus (Markus 5:37; Lukas 8:51), untuk ke gunung bersama-sama dengan Yesus dan menyaksikan Ia berubah rupa di depan mata mereka (Markus 9:2; Matius 17:1; Lukas 9:28), dan untuk menemani-Nya berdoa di Taman Getsemani pada malam menjelang penangkapan-Nya (Markus 14:33; Matius 26:37). Bisa saja murid-murid lainnya memiliki perasaan sakit hati atas keunggulan ketiga murid itu, namun tidak ada catatan di dalam Alkitab mengenai protes mereka. $^{23}$

Malphurs mengatakan bahwa muridmurid adalah orang-orang yang menaati panggilan Yesus untuk mengikuti-Nya dan menjadi orang percaya di dalam Dia. Murid-murid tersebut terbagi menjadi dua kelompok, yakni: the narrow circle (lingkaran yang sempit) dan broader circle (lingkaran yang lebih luas). Kelompok narrow circle adalah dua belas murid,

23 Robert E. Coleman, The Master Plan of Evangelism (Grand Rapids, Michigan: Revell, 2010), 25- 26.

24 Aubrey Malphurs, Strategic Disciple Making: A Practical Tool for Succesful Ministry (Grand Rapids, Michigan: Baker Book, 2009), 49. sedangkan broader circle adalah orang-orang seperti Lazarus, Maria dan Martha, Zakheus, dan lain-lain. ${ }^{24}$

Dengan demikian, nampak bahwa Yesus tidak menghendaki kuantitas tanpa kualitas. Ia memilih orang-orang yang sungguh-sungguh mau menjadi murid-Nya dan mau menjalankan visi yang diberikan kepada mereka. Yesus mengetahui dengan menginvestasikan diri sepenuhnya pada sedikit orang yang menerima visi dari- Nya akan membawa pengaruh yang luas bagi banyak orang di kemudian hari. Kesengajaan pemanggilan murid-murid khusus itu menunjukkan bahwa Yesus memulai proses pemuridan pada level individual. Coleman mengatakan bahwa: "that other things being equal, the more concentrated the size of the group being taught, the greater the opportunity for effective instruction." 25

Ketika Yesus memanggil murid-muridNya, Ia mempunyai sebuah visi yang akan diberikan kepada murid- murid-Nya: "dan kamu akan Kujadikan penjala manusia." Yesus memanggil murid-murid secara sengaja, karena ia memiliki visi bagi mereka. Aubrey Malphurs memberikan sebuah definisi bagi visi: "a vision is a clear, challenging picture of the future of the ministry as you believe that it can and must be." 26 Dengan demikian, sebuah visi merupakan gambaran yang jelas dan menantang mengenai pelayanan yang dapat dan harus terjadi di masa depan.

Kata "Kujadikan" adalah poih,sw yang merupakan kata kerja dalam bentuk indicative future active $1^{\text {st }}$ person singular, memiliki arti "Aku (Yesus) akan membuat". Markus menambahkan kata gene,sqai artinya "menjadi" dalam bentuk verb infinitive aorist middle, mengandung arti hanya dikerjakan sekali saja. ${ }^{27}$ Hal itu berarti bahwa menjadikan penjala manusia merupakan suatu kegiatan yang sedang dilaksanakan Yesus di dalam diri orangorang yang datang kepada-Nya untuk mengikuti-Nya. Frase "Aku akan membuat kamu" memberikan suatu tanggung jawab. Tanggung jawab tersebut diberikan oleh Yesus

${ }^{25}$ Coleman, 26.

${ }^{26}$ Aubrey Malphurs, Developing a Vision for Ministry in the $21^{\text {st }}$ Century (Grand Rapids, Michigan: Baker Books, 1999), 41.

${ }^{27}$ PBIK, 325. 
kepada murid-murid-Nya setelah Ia memberikan pelatihan kepada mereka. ${ }^{28}$ Murid-murid tidak menjadi seperti tujuan Yesus bagi mereka dengan usaha atau kekuatan mereka sendiri, melainkan Yesuslah yang menjadikan mereka menggenapi tugas dan panggilan mereka. Frase "penjala manusia" merupakan visi yang diberikan Yesus kepada murid-muridNya. ${ }^{29}$

Yesus memberikan suatu visi dalam bahasa yang dapat dimengerti oleh keempat orang yang adalah nelayan tersebut. Yesus mengambil gambar diri para murid sebagai nelayan yang menjala ikan-ikan di laut dan membawa mereka pada visi yang lebih luas, yakni menjangkau dan mengubahkan dunia melalui pelayanan mereka. Apabila dibandingkan dengan panggilan Yesus terhadap Matius, maka Yesus tidak mengatakan "penjala manusia" karena pekerjaan Matius adalah pemungut cukai. Yesus mengungkapkan visi yang akan diberikan kepada murid-murid-Nya dengan bahasa yang dapat dipahami oleh mereka. Berkenaan dengan pemberian visi terhadap panggilan Lewi atau Matius, dapat disimpulkan bahwa jawaban Yesus terhadap orang-orang Farisi dan ahli-ahli Taurat yang menegur Dia merupakan visi yang diberikan oleh Yesus kepada Matius yang telah bersedia mengikut- Nya (Matius 9:12-13; Markus 2:17; Lukas 3:1). Visi tersebut adalah penjangkauan orang-orang berdosa supaya bertobat dari dosa-dosa mereka dan berbalik kepada Allah yang hidup. Jadi, di dalam pemanggilan murid, Yesus bukan sekedar memanggil orangorang yang bersedia menjadi murid-Nya, melainkan Ia memiliki visi akan panggilanNya tersebut.

Aubrey Malphurs menyatakan bahwa visi harus dikomunikasikan. Yesus memahami bagaimana Ia harus mengomunikasikan visi-Nya. Dalam mengomunikasikan visi yang penting bagi masa depan sebuah pelayanan melibatkan pengirim, pesan, dan penerima, di mana ketiganya adalah dasar untuk proses

\footnotetext{
${ }^{28}$ Hull, 177.

29 Ibid.
}

komunikasi apa pun dan vital bagi realisasi goal, misi atau misi. ${ }^{30}$ Yesus menyampaikan visi-Nya segera setelah Ia memanggil mereka. Yesus tidak menunda untuk menyampaikan-Nya, apalagi sampai mereka salah paham dengan tujuan panggilan-Nya. Selain itu, Yesus juga menyampaikan visi-Nya kepada para pengikutNya, terutama pada peristiwa menjelang kenaikan-Nya ke surga. Visi pelayanan Yesus yang diteruskan kepada murid-murid-Nya terjadi sejak Ia meninggalkan dunia hingga masa sekarang dan akan terus terjadi selama penyertaan-Nya, yaitu sampai kepada akhir zaman.

\section{KESIMPULAN}

Di dalam pemuridan yang diteladankan oleh Yesus, pemanggilan murid merupakan hal yang penting. Yesus memanggil murid-murid secara Sengaja. Ia memiliki inisiatif untuk mencari murid, bukannya menungggu orang mencari-Nya. Ia menyusuri danau Galilea menawarkan undangan kepada orang-orang yang ditargetkan-Nya untuk menjadi muridmurid-Nya. Pemanggilan murid Yesus merupakan panggilan kepada pertobatan dan mengikut Yesus. Pemanggilan tersebut bukanlah suatu perintah, melainkan suatu undangan yang dapat diterima maupun ditolak. Yesus mengetahui siapa saja yang akan menerima undangan-Nya. Berdasarkan pernyataan-Nya, "Aku datang bukan untuk memanggil orang benar, melainkan orang berdosa" (Matius 9:13) maka diketahui bahwa Yesus hanya memanggil orang-orang yang berdosa. Roma 3:23 menyatakan bahwa "semua orang telah berbuat dosa dan telah kehilangan kemulian Allah."Maka, tidak ada orang benar. Kata "orang benar" yang dimaksudkan oleh Yesus berasal dari kata di,kaioj (dikaios) yang mengandung arti orang yang merasa dirinya benar, yang membanggakan dirinya sebagai orang benar dalam menaati hukum Taurat dalam kebajikan baik itu kenyataan atau dibayangkan. Ia mencari orang-orang berdosa untuk memberitakan kepada mereka berita tentang pertobatan dan pengampunan di dalam Kristus dan menawarkan kepada orang-orang tersebut untuk percaya kepada Kristus dan mengikuti

\footnotetext{
${ }^{30}$ Malphurs, Developing a Vision for Ministry in the $21^{\text {st }}$ Century, 84.
} 
Dia. Ia menawarkan dirinya untuk menolong mereka memiliki hubungan pribadi dengan Tuhan dan hidup dalam ketaatan, pertobatan, ketundukan dan komitmen kepada-Nya.

Jadi, sebagaimana yang telah dilakukan oleh Yesus, maka seseorang yang mau memuridkan seharusnya secara sengaja pergi untuk mencari murid-murid bagi Kristus. Ia harus mendoakan terlebih dahulu secara sungguh-sungguh tentang siapa orang-orang yang akan dimuridkannya. Ia tidak memilih mereka berdasarkan kehendaknya sendiri, akan tetapi berdasarkan kehendak Bapa yang diketahuinya melalui doa. Kepada

orang-orang tersebut, ia akan menginvestasikan hidupnya sepenuhnya untuk memuridkan mereka. Selain itu, seperti yang telah diteladankan oleh Yesus, seseorang yang memuridkan harus memiliki visi yang jelas dan dapat mengomunikasikan visi tersebut kepada murid-murid-Nya. Visi itu adalah menjadikan orang lain murid Yesus. Ketika seseorang bersedia untuk dimuridkannya, maka ia harus segera menyampaikan visi pemuridan itu kepada calon murid. Ia harus memastikan orangorang yang dimuridkan-Nya dapat menangkap visi tersebut dan memberikan tanggungjawab kepada murid-muridnya untuk dapat melaksanakan visi itu serta dapat mengomunikasikan visi itu kepada orang- orang lain yang akan mereka muridkan kelak.

\section{REKOMENDASI}

Ada beberapa rekomendasi untuk penelitian selanjutnya. Pertama, diharapkan ada penelitian mengenai efektifitas penerapan pemanggilan murid secara sengaja berdasarkan teladan Yesus oleh gereja-gereja sebagai penerima Amanat Agung. Kedua, diharapkan ada penelitian mengenai teladan Tuhan Yesus berkenaan dengan pengajaran yang diberikan kepada murid-murid yang telah dipanggil-Nya secara sengaja untuk melaksanakan visi yang ditetapkan-Nya untuk menjadikan segala bangsa murid Kristus. Ketiga, diharapkan ada penelitian mengenai keberhasilan maupun kegagalan para murid Yesus dalam menjalani panggilan mereka sebagai murid Yesus.

\section{DAFTAR PUSTAKA}

Boice, James Montgomery. Christ's Call to Discipleship (Grandrapids, Michigan: Kregel Publications, 1998.

Boice, James Montgomery. The Gospel of Matthew Volume 1. Grand Rapids, Michigan: Baker Books, 2001.

Bonhoeffer, Dietrich. The Cost of Discipleship. London: SCM Press, 2001.

Coleman, Robert E. The Master Plan of Evangelism. Grand Rapids, Michigan: Revell, 2010.

Dallas Theological Seminary: Bibliotheca Sacra Volume 160. Dallas Theological Seminary, 2003; 2004, S. vnp.160.638.221-160.638.234.

Gibbs, Eddie. Kepemimpinan Gereja Masa Mendatang. Jakarta: BPK Gunung Mulia, 2010.

Hull, Bill. Choose the Life. Surabaya: Literatur Perkantas Jawa Timur, 2012.

Hull, Bill. The Complete Book of Discipleship. Colorado Springs: NavPress, 2006.

Hull, Bill. The Disciple-Making Pastor: Leading Others on the Journey of Faith. Grand Rapids, Michigan: Baker Books, 2007.

Malphurs, Aubrey. Developing a Vision for Ministry in the $21^{\text {st }}$ Century. Grand Rapids, Michigan: Baker Books, 1999.

Malphurs, Aubrey. Strategic Disciple Making: A Practical Tool for Succesful Ministry. Grand Rapids, Michigan: Baker Book, 2009.

Moore, James W. Jesus Parable about Discipleship. Nashville, Tenessee: Abingdon Press, 2009.

Ogden, Greg. Transforming Discipleship. Illinois: Intervarsity Press, 2009.

Perjanjian Baru Interlinear Yunani-Indonesia dan Konkordansi Perjanjian Baru (PBIK), diterjemahkan oleh Hasan Sutanto. Jakarta: Lembaga Alkitab Indonesia, 2006.

Russ, Eric. Discipleship Defined. Maitland, Florida: XulonPress, 2010.

Villafane, Eldin. Beyond Cheap Grace: A Call to Radical Disciplehip, Incarnation, and Justice. Grand Rapids: Eerdmands, 2006. 
Wagner, C. Peter. Strategi Perkembangan Gereja. Malang: Yayasan Penerbit Gandum Mas, 1996.

Tafsir Perjanjian Baru 3: Injil

Lukas. Yogyakarta: Kanisius, 1989. 